\title{
Women Refugee Discrimination: A Critical Review of the Women's Rights Fulfillment in Mount Sinabung Eruption Refugees
}

\author{
Nurlela, T.Silvana Sinar, T.Thyrhaya Zein,Fernanda Putra Adela \\ Lecturer of Linguistics Faculty of Cultural Science University of North Sumatra
}

\begin{abstract}
This paper discusses and criticizes government policy in tackling women refugees due to eruption of Mount Sinabung which has lasted for 7 years (2010-2017). Women refugee are trapped in the central and local government policies that are very 'masculine' in tackling their problems. The various problems they face do not count as a problem. This is evident from the abandonment of domestic needs for menstruating women, pregnant women, lactating women, and women who have multiple roles as wives and mothers for their children. The author articulates a model of symbolic interaction to understand new issues of government policy over the years. At the end of this paper the authors convey the identification of the problems faced by women refugee in refugee camps and recommend reconstruction policies related to the problems they face.
\end{abstract}

Keywords: women refugee, rights fulfillment, government policy.

\section{INTRODUCTION}

Women are a vulnerable group in the eruption of Mount Sinabung disaster in Karo district that has been going on regularly in the last 7 years (2010-2017). Women refugee experience very complex conditions, both economically, physically, and socially. The main problem is not only related to physical problems, such as disruption of the needs of clothing, food, health, and education, but including the fulfillment of their rights as women.

The problem mentioned are appears from the lack of availability / limited public facilities, social, sanitation, inappropriate place, the duration of evacuation, until uncertain weathers causing a sense of discomfort. If these bad conditions continue to be ignored, it can be ascertained that the location of the refugees will become the source of the some diseases even the cause of death. In addition, the victims of Mount Sinabung eruption were forced to lose their possessions which caused the victims to become impoverished. Not only that, the source of the daily livelihood of the people such as agricultural land is also damaged (Karen, 2013).

Empirically, when disasters occurred, women and children are more likely to be the first victims. Because, women are become permanent residents, while men are always synonymous with making a living. The interaction of women with the environment is very dominant, such as women who take water from the river for family drinking, pick vegetables and tea leaves that are mostly women. This is also the case of the volcanic eruption of Mount Sinabung (Charan, 2013: 106-122).

Another big problem, they lost family members, especially the source of family breadwinners caused by the volcanic eruption of Mount Sinabung. This often leads to anxiety, fear and even prolonged trauma. Assistance from various sources in the form of materials may be able to meet the physical needs of disaster victims, especially women, but this does not necessarily solve the problems they face.

Other adversities which are faced by women refugee are concerning the psychological problems, such as fears of subsequent eruptions and longing for the conditions as they were before the disaster. In addition, they are forced to live in evacuation under limited conditions (Suardiman, 2001).

It is increasingly difficult for the conditions of the women refugee that they often ignited conflict between their fellow for various reasons. In addition, most of these refugees have livelihoods as farmers who are used to working hard from morning to night. While in the refugee camp they do nothing and keep silent, without doing activities that can support financial needs, so routines like this make the refugees feel bored.

Mount Sinabung eruption refugees who for many years lived in evacuation locations such as loss of self-esteem, self-confidence and social identity, this conditions impressed they resigned to accept this situation, helpless in the face of the future and blame each other when the late arrival of assistance from the government.

Not only that, a sense of despair by blaming God for the calamity that befell them is 
often heard. Some refugees cannot refuse to move to a new place because their homes are no longer suitable for habitation is also a problem to be addressed.

The problems faced by men and women in refugee camps have a very different level of problems. This is because the problems faced by women are more complex. In general, women's issues are closely related to security issues in refugee camps. Because, women refugee of Mount Sinabung eruption requires a closed shelter, separated from male refugees, and bathrooms separated from men.

The problem as described above is a problem that until now has not been resolved at the evacuation site in Karo District. For example, a women's bathroom blends with a men's bathroom, how many doors do not have a lock, and no good light because of the dim lights. Then, women refugee who actually need clean water in addition to cooking, urinating and bathing, sometimes lack of water in the bathroom. The facilities received by women in evacuation are inversely proportional to the needs of women for their domestic (private) needs, such as; refugee women who have are in their periods, pregnant women and women who play double roles as mothers and wives.

Based on data obtained by a team of researchers from the Regional Disaster Management (BPBD) Karo District, from the eight evacuation sites there are 7,214 people who are still living in the refugee, with details; 3,567 men and 3,647 female refugees. (Data from BPBD Karo district)

A non comprehensive, effective, and perspectively refugee handling system is essential to minimize the deterioration of women refugee conditions. The perspective can be pioneered with the sensitivity to form a disaggregated database, so that identifies the specific needs of women refugee services from the beginning they are in evacuation.

The article entitled: "Women Refugee Discrimination: A Critical Review of the Women's Rights Fulfillment in Mount Sinabung Eruption Refugees" is the author's reflection on violence against women refugeen. Sourced from the limitations of space and the movement of women in discriminated groups, access to information and policies ultimately make them vulnerable.

\section{RESEARCH METHODOLOGY}

This study is a qualitative research with descriptive research type. Primary data used comes from interviews, while secondary data obtained by researchers from international journals, national journals, books and media releases. The collection of research data is also done through a review of documents or reports related to the research focus. The author combines the Marxist, phenomenological, feminist and etnometodological perspectives in exposing violence and power relations that make women as the main victims of agrarian conflict in Mekar Jaya.

\section{RESULTS AND DISCUSSION}

\section{A. General Condition of Mount Sinabung}

Territorially Mount Sinabung is located in Karo Regency which is one of regencies in Sumatera Utara Province with 2,127.25 $\mathrm{km}^{2}$ or $2.97 \%$ of Sumatera Utara Province. Since 2010 until 2017 Mount Sinabung has been routinely erupted. Recorded since 2010 mount Sinabung has experienced eruption in 2010, 2013, 2014 and 2017.

Towering high 2,460 meters from sea level (asl), Mount Sinabung stretches with eruptions on different scales. The eruption, accompanied by a rumbling sound of black smoke and gray matter volcanic ash. This blowing leads to the East, Southeast, and South.

Volcano Monitoring in Kabanjahe noted the height of the material throw reaches 3000 meters. According to the Center for Volcanology and Geological Hazard Mitigation (PVMBG), the eruption record of Sinabung Volcano in 1600 with volcanic activity in the form of pyroclastic rock vomit and lava flows flowing to the south. Later in 1912, this mountain produced a solfatara seen at the top and the upper slope. After nearly 100 years, this strato type volcano erupted again. In 2010-2017 periodically occur several times the eruption of which in the form of phreatic eruption.

According to Natanail Perangin-angin, Head of Emergency and Logistics BPBD Karo said: 
"Secara substansi dasar upaya penanggulangan bencana di Gunung Sinabung dalam 7 tahun ini secara berkala menitikberatkan pada tahap kesiapsiagaan sebelum bencana terjadi, mengingat bahwa tindakan preventif (mencegah) lebih baih daripada Kurativ (penanganan). Bencana alam sendiri memang tidak dapat dicegah namun dampak buruknya dapat dicegah dengan kesiapsiagaan sebelum terjadi bencana." (wawancara 20/11/2017)

\section{B. Women Discrimination in Refugees Camp}

In the evacuation camp of Mount Sinabung eruption victims, women always experience greater risks than men because of the lack of protection against them. This is because the risks faced by women include the potential faced by women who are often victims of exploitation, sexual harassment, violence, forced marriage, reproductive diseases, and even death.

Moreover, specific problems in evacuation sites are often experienced by women, among others, the emergence of psychological instability, reproductive health problems, and pregnancy are often considered not urgent. Because in general, health handling of women victims by the eruption of Mount Sinabung more emphasis on victims who suffered physical injured. (Martiany, 2015)

Not only that, the discrimination faced by women refugee is often present in discriminatory policy forms. According to Nande Roma who is one of the woman refugee who was in the refuge for 2 years.

"Di pengungsian yang
dibutuhkan pengungsi adalah air
bersih yang melimpah. Sebab, hal ini
banyak berguna untuk membersihkan
kain yang digunakan ketika sedang
mentruasi. Nyatanya pemerintah
sempat membangun bilik asmara yang
sebenarnya kita tidak gunakan"
(Wawancara 17/9/2017)

The Problem in evacuation sites are often the lack of clean water. So women refugee often difficult to clean and throw away the sanitary napkins they used (towel). Furthermore, for sanitary napkins obtained from the government, volunteers as well as the help of entrepreneurs is so minimal. Not only that, the conservative women refugees do not use sanitary napkins.

Moreover, many of women refugee who still have children under five, another problem is when she often difficult to feed her children who are fed with food provided by the evacuation committee. This is certainly a problem for these refugee women because of their role as mothers of their children and wives for their husbands. (Ware, 1981)

The pressure faced by women in refugee camp occurs through a very long process in a patrilineal cultural system. This is reflected in many of the gender differences caused by, among other things, being shaped, socialized, reinforced, even socially constructed by this cultural system. For refugee women in refugee camps, this inconvenience makes women experience psychological distress.

Harmonization in life with families who are usually free to gather with children and husbands in the privacy room no longer occur. Conversely, at the evacuation site, the pressure of feelings and actions to join the other refugees creates a sense of discomfort. As a result, it is not surprising that women in the refugee camp feel isolated and alienated. At the refugee camps, refugee women find it difficult to communicate privately in relation to women's issues among themselves. In fact, women need a place to share stories and pour out the hearts of fellow women to eliminate the psychological burden.

The absence of this privacy room for women, causing women to have difficulty to change clothes, as well as difficulty to care or treat the parts of the body inside (vital) that caused the pain, so that certain parts of the sick is often neglected. They tend to leave the sick without medication, with shame if the illness is known to others, and ashamed if the parts of the body are seen by others. At the evacuation site of Mount Sinabung eruption, the hopes of obtaining that privacy space were also voiced by refugee women.

C. Giving access to refugee women through Policy Collaboration 
One of the government's efforts to solve the eruption problem of Mount Sinabung eruption is to establish refugee posts to identify the eruption of Mount Sinabung eruption. The disaster of Mount Sinabung eruption should be focused on helping the victims, but in reality there are still irregularities. The refugees rely more on the assistance of other citizens than government assistance. Then, the policy of the government during this time is very masculine and less attention to the domestic aspects of women.

Refugee women are very sensitive to the survival of their children who must also be considered by the stakeholders. The location of the refugee that is currently where they spend their time and place raising their children requires adequate facilities in order not to affect the occurrence of things that harm the child, such as school dropouts or children experiencing a cost of living during school delay. In this regard, women must be strong and tough in facing challenges, women cannot accept fate simply, but they must be able and adapt to create a strategy to find a solution so that they can continue the survival of their family. In this case, it may not be agreed upon by the opinion of adherents of fatalist groups who view women as a resigned and acceptable group. In fact, women can get out of the circle of destiny that befalls him, so she can meet the needs of family life.

Collaboration is a collective process in the formation of a group based on mutual relations (mutualism) and cooperation of organizational goals or individuals who choose autonomous nature. They interact and negotiate both formal and informal in a mutually agreed and mutually trusting rule. Although the outcomes or ends of a collaborative process may be private, they still have other group results or benefits. (Dye, 2005)

This collaboration is co-operative with personal involvement among stakeholders such as governments, employers, NGOs, academics, the media and the community in achieving an optimal solution to their problems.

\section{CONCLUSION}

At the end of this paper, the author answers basic questions about women's discrimination in refugee camps. Departing from the limitations of women's accessibility to information, policies and discrimination in refugee camp causes refugee women to be vulnerable groups.

Refugee women have a very complex responsibility in the middle of their position as wives and mothers for their children. They are responsible for providing food for their husbands and children, and are also responsible for the future of the child. Beyond that, there are domestic problems that women refugees themselves are saving when they experience violence both verbally and physically in the refugee camps. The problem of menstrual women and the circumstances of pregnant women in refugee camps is neglected and never counted as a serious problem. Not to mention the socially or financially messy lives, because they have lost their homes, farms, and psychological effects of past memories when they were in the village they left behind.

This paper concludes with the writer's attitude about the role of the state which includes both central and local governments that have not been aligned with women refugees. States and governments must be able to accommodate the interests of refugee women so that they avoid both verbal and physical violence.

During this time, disaster management is considered not a priority and only comes at any time. And we live in areas prone to the threat of disaster. Therefore understanding of disaster management needs to be understood by all circles, both government, society, and private. Not only that the refugee policy during this time is very masculine.

At the end of this paper the right recommendation is the collaboration of stakeholders such as; government, academicians, businessmen, NGOs and community media in the handling of refugees, especially women refugees, together with regulatory sanctions against women IDPs. Not only that, the need for local regulations (Perda) in the handling of refugees who pay attention to women refugee issues need to be implemented.

\section{REFERENCES}

\section{Books:}

Denzin, Norman K dan Yvonna S Lincon (2009), Handbook Of Qualitative 
Research, Yogyakarta : Pustaka pelajar.

Dye, Thomas, 2005, Understanding Public policy, United State : Upper Saddle

River, New Jersey.

Suardiman, Siti Partini (2001), perempuan kepala rumah tangga, Yogyakarta :

Jendela.

Ware, Helen (1981), Women, Demografhy, dan Development, canberra : The Australian National University.

\section{Journal:}

Bird, Karen, 2013, The Political Representation of Women and Ethnic Minoritie in

Established Democracies:A Framework for Comparative Research, Working Paper presented for the Academy of Migration Studies in Denmark (AMID),Aalborg University11 November 2013

Charan, Dhrishna Manpreet Kaur dan Priyatma Singh (2013), Indigenous Fijian Women's Role in Disaster Risk Management and Climate Change Adaptation, University of Fiji Journal, hal. 106-122.

Martiany , Dina, 2015, Penanganan Pengungsi

Perempuan, Kajian Singkat Terhadap Isu Aktual Dan Strategis, Jurnal Kesejahteraan Sosial Vol. Vii, No. 14/Ii/P3di/Juli/2015 Hal 9-12.

\section{Document:}

Data from BPBD Karo Regencies 